\section{Ultralyd ved pneumoni hos barn?}

Ultralydunders $\varnothing$ kelse ved mistanke om pneumoni hos barn kan ha høy diagnostisk sensitivitet og spesifisitet, viser en ny metaanalyse.

Røntgenundersøkelser er mye brukt for å stille diagnosen pneumoni, men pga. den ioniserende strålingen er mange tilbakeholdne med slike undersøkelser, spesielt hos barn. I en metaanalyse, som nylig er publisert i tidsskriftet Pediatrics, har man undersøkt den diagnostiske treffsikkerheten av ultralydundersøkelse ved mistanke om pneumoni hos barn (1).

Analysen omfattet åtte studier med totalt 765 barn med klinisk mistanke om pneumoni og/eller en bekreftet pneumonidiagnose ved bildeundersøkelse, dvs. røntgen eller cerebral computertomografi (CT). Totalt hadde ultralydundersøkelse en diagnostisk sensitivitet på 96 \% (95\% KI 94-97\%) og en spesifisitet på $93 \%(90-96 \%)$.

- Denne studien er et eksempel på metodeevaluering der grunnleggende prinsipper for god, radiologisk forskning er tilsidesatt, sier Karen Rosendahl ved Radiologisk avdeling, Seksjon for barn, Haukeland universitetssykehus (2).

- Metaanalysen omfattet få, relativt små og heterogene studier. Undersøkeren hadde kjennskap til kliniske data, noe som kan ha ført til en vurderingsskjevhet, og kriteriene for pneumonidiagnosen varierte mellom studiene. Metaanalysens rapporterte sensitivitet og spesifisitet er således beheftet med betydelig usikkerhet, sier hun.

- At ultralydundersøkelse kan være et nyttig diagnostisk hjelpemiddel i en akuttsituasjon er velkjent, men om det kan erstatte røntgen ved diagnostikk av pneumoni hos barn, er usikkert. Og hvorfor erstatte en rask, velfungerende og ufarlig metode - stråledosen tilsvarer kun 1-3 døgns normal bakgrunnsstråling - med en undersøkelse som tar lengre tid og kan være besværlig for både barn og undersøker? spør Rosendahl.

\section{Lise Mørkved Helsingen}

Tidsskriftet

\section{Litteratur}

1. Pereda MA, Chavez MA, Hooper-Miele CC et al. Lung ultrasound for the diagnosis of pneumonia in children: a meta-analysis. Pediatrics 2015; 135 : $714-22$

2. Fryback DG, Thornbury JR. The efficacy of dia gnostic imaging. Med Decis Making 1991; 11: 88-94.

\title{
Mødredødelighet og avstand til sykehus i Tanzania
}

\section{Tanzania er mødredødeligheten høy. Lang avstand til sykehus er for- bundet med økt dødelighet av direkte obstetriske årsaker, men ikke av andre årsaker.}

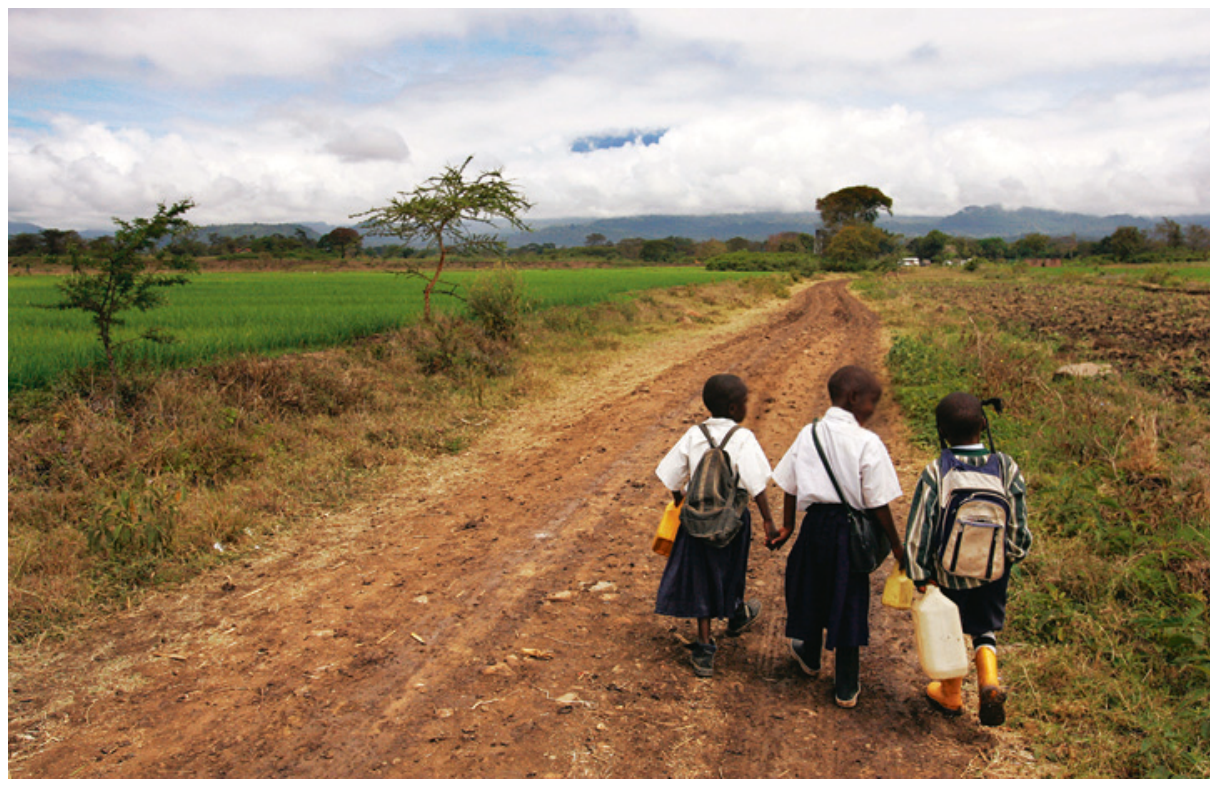

Illustrasjonsfoto: AFP/Scanpix

Dette viser en fersk studie (1). Svangerskapsrelaterte dødsfall er et betydelig helseproblem i mange land, og reduksjon av mødredødelighet var ett av FNs åtte tusenårsmål. Dødsfallene kan deles $\mathrm{i}$ to hovedgrupper: direkte obstetriske årsaker, f.eks. blødninger, eklampsi m.m., og indirekte årsaker, f.eks. malaria, hiv m.m.

I studien så forskerne på forekomsten av mødredødelighet og sammenhengen mellom dette og avstand fra bosted til nærmeste sykehus. Forskerne intervjuet 225980 husstander sørvest i Tanzania i 2007. Blant 193867 kvinner i fertil alder ble det rapportert 64098 levendefødte barn i studieperioden 2004-2007. Man fant en større andel sykehusfødsler jo kortere avstand det var til nærmeste sykehus. I 439 av 507 svangerskapsrelaterte dødsfall ble dødsårsaken bestemt i etterkant, basert på spørreskjemaintervju. Det ble funnet direkte obstetrisk dødsårsak hos 162 og indirekte obstetrisk årsak hos 95 kvinner, mens dødsårsaken var ukjent eller ikke-klassifiserbar hos resten.

Total svangerskapsrelatert mortalitet var
712 per 100000 og viste ikke sammenheng med avstand til sykehus. Derimot fant man en assosiasjon med avstand til sykehus når man kun inkluderte dødsfallene med direkte obstetrisk årsak, som var tre-fire ganger så hyppig blant de som bodde $>35 \mathrm{~km}$ fra sykehus som blant de som bodde $<5 \mathrm{~km}$ fra sykehus ljustert oddsratio $3,68,95 \% \mathrm{KI}$ 1,37-9,88). Forfatterne konkluderer med at lang avstand til sykehus bidrar til høy maternell dødelighet, men at høy total dødelighet blant de som bor nært sykehus, dessuten tyder på dårlig kvalitet i helsetilbudet som gis ved sykehusfødslene.

\section{Kristoffer Brodwall}

kristoffer.brodwall@gmail.com

Institutt for Global helse og samfunnsmedisin

Universitetet i Bergen

\section{Litteratur}

. Hanson C, Cox J, Mbaruku G et al. Maternal mor tality and distance to facility-based obstetric care in rural southern Tanzania: a secondary analysis of cross-sectional census data in 226000 households. Lancet Glob Health 2015; 15: 1-9. 